This document is the post-peer review version of the following published article:

Kelsey, P. and Ramaswamy, M. (2004). "Designing a Successful Library School Field Experience." Library Management, 26(6/7): 311-323.

\title{
Designing a Successful Library School Field Experience
}

\section{By Paul Kelsey and Mohan Ramaswamy \\ INTRODUCTION}

A recent library school graduate, in response to an ACRL report listing "Recruitment, education, and retention of librarians" as a top issue, stated "it's not easy to find an entrylevel position in an academic library these days; available jobs increasingly require skills and specializations...from second master's degrees or significant time in other job sectors." (Paulson, 2003). How do library school students acquire the work experience and skills so vital to finding employment as information professionals? Brett Singleton's tips for library school students recommend taking advantage of internship "opportunities for exploring, learning, and mentoring..." in order to find professional employment after graduation. (Singleton, 2003). Internships, practicums and field experiences offer exceptional opportunities for library school students to pursue professional level work under the supervision and mentoring of a professional librarian.

The Louisiana State University Libraries (LSU Libraries) participates in the field experience program offered through the LSU School of Library and Information Science (LSU SLIS). The present case study took place at the LSU Libraries during the 2001 fall semester, and the co-authors (the supervisor and the student) share their viewpoints and discuss the merits of their field experience. The authors subsequently developed a paradigm built upon the success of the current case study. The purpose of the article is to 
provide a practical model for other supervisors and students to follow in order to design a highly successful library field experience, internship, or practicum.

\section{LITERATURE REVIEW}

Like any professional education, learning to be a librarian is incomplete without a form of exposure to practical aspects and hands on experience. Coburn (1980) provides a historical overview of library internship, portraying the evolution of library education. For example, between 1887 and 1922, organized library training programs evolved, replacing the erstwhile unsystematic training of librarians. Willamson's (1923) report raises several questions on the objectives and procedures of professional training, inspiring the advancement of field experience programs from 1923 to the present. Contemporary programs exist in several formats customized to the needs of today's library school student.

Professional skills need to be instilled in library graduates before they enter the work place, and field experiences offer an exceptional method to accomplish this objective. Increasingly, fresh graduates with little library experience cannot find entrylevel academic librarian positions (Paulson, 2003). And it takes a lot more qualifications and skills than just an MLIS degree to secure a job (Singleton, 2003). While some skills can be imparted on-the-job, graduates need many basic skills before beginning a professional career. Lawson (1981) recognizes the advantages of promoting library internship, addressing the library school students' inadequate experience and exposure to the field. Librarians need expert knowledge and skills to be effective in the ever changing library environment (Creth, 1986). Jain's (1999) survey research reveals the importance of on-the-job training in human resource development and identifies key training areas 
for Botswana library professionals. Becker (2000) demonstrates that "service learning" is a strong tool to educate and prepare librarians for the new millennium.

Field experience programs have potential roles beyond basic training. Apart from learning professional skills, trainees gain-confidence from working with a librarian (Daix and Epps, 2001). Creth (1986) lists several options including coaching, role modeling, and goal setting. The trainee's participation in library committees and meetings, workshops, and conferences offer additional training avenues. Library internship programs also serve as catalysts to bring diversity into academic librarianship (Daix and Epps, 2001). Cogell and Gruwell (2001) have compiled the experiences of many libraries using residency programs to build diversity.

Whitmire (2001) provides a comprehensive overview of the professional development opportunities of Yale University's residency program. Most practicum students are mentored to pursue professional activities like participating in conferences and sharing professional experiences. Such activities help the trainee to acquire professional attitude and collegial relationship. Fischer's (1994) guide illustrates the history, theory, and practice of mentoring in a library setting, and includes a related bibliography.

Rowley (1999) discusses the circumstances and problems related to work-based projects and how the supervisor can address those. Inspired by personal experience, Brewer (2001) narrates the roles of the residents and supervisors in developing work assignments, maintaining effective communication, and evaluating the success of the residency program. As libraries venture into innovative training avenues, it is imperative 
to look at the experiences of other residency programs to adopt already standardized training and management techniques.

Because field experiences empower library science graduates, library schools promote their program via magazines and journals. For instance, Oberg and Samek (1999) published the merits of the practicum program offered at the University of Alberta. Their article explains how their practicum program focuses on training their students in reference, cataloging, technology, records management, and more. Publicizing the students' positive experiences helps library schools to recruit new students.

\section{FIELD EXPERIENCE DESCRIPTION}

The primary purpose of the LSU SLIS field experience program is to provide students with the opportunity to acquire professional skills and work experience in a library or information center environment. Each SLIS student is matched with an information professional responsible for supervising and actively participating in the field experience (SLIS, 1995). The field experience supervisor works with the student to plan the field experience and is responsible for providing all of the on-site training and professional guidance necessary to ensure a successful experience. Applying the theoretical principles taught in library school to practical work experience in a professional setting is strongly emphasized, and the student is encouraged to pursue a field experience commensurate with his or her career objectives. A student is expected to acquire knowledge of daily operational procedures of the library environment and complete a specific project(s) that "will be valuable to the personnel at the field experience site." (Guidelines, p. 4). The specific project(s) represents the type of work the student will encounter in a subsequent career as an information professional. Hence, the SLIS field experience "is intended to 
provide students with a meaningful and valuable orientation to the professional world." (SLIS, 1995).

The procedural responsibilities of the field experience, including documentation and evaluation, rest with the SLIS advisor, the student, and the supervisor. First, the student prepares a set of field experience goals and objectives for approval by the SLIS advisor. The advisor helps the student identify appropriate field experience settings and potential supervisors, and the student is responsible for arranging the initial meeting with the supervisor to discuss the field experience. The supervisor and student develop a plan of work together that includes a description of the field experience activities and project. The LSU Libraries requires the supervisor to submit a memorandum to the Dean of Libraries describing the experience and how it will affect the work of the department, and the amount of time the faculty member will spend supervising the student. A field experience contract is then signed by the student, supervisor, and SLIS advisor, and all three meet for two scheduled conferences during the semester. The student maintains a $\log$ documenting the activities of the field experience and writes a project report to submit to the advisor at the end of the semester. The supervisor completes a formal evaluation of the student, and the advisor assigns a grade. The field experience consists of 120 hours of work, and the SLIS student receives three hours of graduate credit applied toward the MLIS.

The field experience provides a springboard for the student to successfully transition into a professional career. The field experience allows the student to identify the following elements of the information or library environment: 
1. The community served, and the relationship between the community and the library, department or information agency

2. The goals and objectives of the library, department or information agency

3. Services or programs offered, and the methods used to evaluate them

4. The role of the personnel

5. Equipment and layout

6. A knowledge of budgetary processes and the means used for allocation of resources

7. The role of the manager or supervisor

8. The strengths and weaknesses of the library, department or information agency (SLIS, 1995)

The SLIS student should be able to conceptualize and describe the dynamic interrelationships of these elements in a professional environment by the time the field experience comes to a close (SLIS, 1995).

\section{FIELD EXPERIENCE ANALYSIS}

The supervisor, the student, and the advisor will all invest a considerable amount of time, energy, and professional and personal involvement in the field experience. In many cases, field experiences provide students with their first introduction to the professional world of librarianship. Field experience students have a right to expect a well-planned, carefully supervised practicum with a successful outcome. Careful planning by everyone involved during the initial stage of the field experience is critical to ensure a meaningful and productive practicum for the student. Field experience guidelines may provide a list of field experience goals and objectives, administrative procedures and responsibilities, a 
contract, and perhaps some general project examples, but sometimes lack helpful suggestions for actually designing the experience. The following paradigm offers a model with easy steps to follow to help supervisors, advisors, and students plan for a successful field experience in any type of library or information center. The paradigm is divided into two sections: a paradigm for supervisors (librarians and other information professionals) and a paradigm specifically for library school students. The following analysis covers each step from the paradigm and provides corresponding examples from the LSU Libraries field experience.

\section{A. PARADIGM FOR SUPERVISORS}

\section{Planning}

The library supervisor should begin the initial planning stage in advance of the start date of the field experience. The supervisor first identifies possible projects for the field experience, meeting or consulting with the student to determine areas of possible interest for the field project(s). The supervisor then selects a project corresponding to the student's professional goals and interests, and if the experience guidelines stipulate the completion of a project for credit, one that the student can realistically complete in a timely manner. The project(s) should consist primarily of professional level work and provide the student with the professional level experience required to find subsequent employment. Therefore, selecting paraprofessional projects will not meet this requirement. Additionally, a paraprofessional project may not allow the student to effectively apply concepts learned in library school or to directly experience the life of a library or information professional. Ideally, supervisors should allow field experience students to directly participate in their own professional work or projects. For example, 
the librarian can ask a student to take part in a project in progress or begin a new project already planned. Students should be encouraged to work in tandem with their supervisor on other duties that are part of the librarians' daily professional lives. For example, students can work with the supervisor at the reference desk, take part in an instruction session, or work with him or her on a PowerPoint ${ }^{\circledR}$ presentation. The most important aspect of the field experience consists of allowing students to participate in professional level projects and responsibilities.

Planning tools enable the supervisor to effectively design and manage the field experience. The supervisor should create an outline with the percentage of time devoted to each project. If only one project is selected, the percentage of time allocated for each stage of the project should appear in the outline. The student should read the outline and provide input to the supervisor. The outline allows the supervisor to monitor the student's progress and ensure that the project is completed on time. The outline also gives the supervisor some flexibility to change the percentages during the course of the field experience to adjust for the student's rate of progress. The supervisor should always select an additional project to hold in reserve in case the student finishes earlier than anticipated. Maintain an Excel ${ }^{\mathbb{}}$ spreadsheet to document the project hours as the field experience progresses.

During the LSU field experience, the supervisor selected several projects for the student. Each project consisted primarily of professional level work, and included updating collection development pages, selecting appropriate titles to order for the collection, identifying core journals in Journal Citation Reports (JCR) for collection management, weeding the collection, developing agricultural subject guides, designing 
database handouts for the reference department, assisting in answering reference questions, investigating possible web sites for an AgNIC partnership, creating PowerPoint ${ }^{\circledR}$ presentations for instruction sessions, and identifying resources for professional development and potential employment. The supervisor designed the experience to allow the student to participate in a variety of professional projects appropriate for a science librarian. The supervisor created and maintained an outline with the percentage of time allocated for each duty, working with the student to document the hours on a spreadsheet.

\section{$\underline{\text { Training }}$}

After identifying appropriate projects, the supervisor normally provides all of the training necessary for the student to successfully complete the field experience. Without the appropriate training and guidance, the student cannot fully benefit from the supervisor's professional experience and knowledge. Occasionally, the supervisor will need to work together with the student on projects in order to stay involved and to give the student an opportunity to ask questions. Ideally, the field experience supervisor will arrange to meet at least weekly with the student - other options include communicating over the telephone and via email. The supervisor should seek student input on a regular basis. Frequent communication fosters the student's motivation and will result in a more meaningful and rewarding experience for both parties.

The supervisor of the LSU field experience provided in-depth training sessions (an hour or longer) for each of field experience projects. In addition, the supervisor and student worked together on a PowerPoint ${ }^{\circledR}$ presentation for an instruction session, weeding the entomology collection, developing subject guides and maintaining collection 
management pages related to the LSU College of Agriculture, and identifying Internet resources for professional development and potential employment. The supervisor scheduled weekly meetings to discuss the projects with the student and often communicated with the student by phone or email. The supervisor encouraged the student to ask questions and to provide input regarding each of the projects. The supervisor's ongoing efforts to offer professional training, guidance and advice for the student resulted in a beneficial and meaningful field experience.

\section{Mentoring}

Mentoring is perhaps the most important aspect of a successful field experience. With their extensive experience and knowledge, supervisors find themselves in the position to readily assume the role of mentor, par excellence. Career counseling and establishing a professional rapport with the student mentee are recommended as part of the mentoring process. The supervisor can suggest job listservs and appropriate professional organizations for the student to join, and even help the student join a committee. The supervisor can show the student job web sites for potential employment, cover interviewing strategies and skills, and volunteer to write letters of recommendation for the student. Establishing professional rapport will require supervisors to view students as potential colleagues and to develop a positive working relationships with them. Professional rapport and collegiality will often develop into a friendship that extends beyond the field experience and well into the student's career. The supervisor and the student are encouraged to explore publishing opportunities together and to give joint presentations at professional conferences. 
In the present case study, the supervisor provided fairly extensive career counseling for the student. Career counseling consisted of recommendations for joining ALA and USAIN, signing up for the USAIN listserv, advice for identifying and joining appropriate committees, tips for professional networking, showing the student the ALA Education and Careers web site, tips for interviewing, and advice regarding the publishing process. The supervisor also served as a professional reference and wrote several letters of recommendation for the student. The student and the supervisor gave a joint presentation at the ALA Midwinter Conference and co-authored the present publication. The supervisor and the student maintain close contact and have become professional colleagues.

\section{$\underline{\text { Evaluation }}$}

Providing ongoing evaluation will enable the supervisor to effectively meet the administrative requirements for the field experience. The library school will typically require the supervisor to submit a formal evaluation of the student and documentation of the field experience project(s) at the close of the practicum. By maintaining an ongoing record of the hours completed on a project and regularly evaluating the student's performance, the supervisor can easily complete the necessary documentation. The dean of the library may require the supervisor to submit documentation of the field experience in addition to any materials submitted to the library school. The supervisor is advised to review library administrative requirements before the actual start of the practicum. The supervisor's requirements for the student (including scheduled hours, documentation of work, progress reports, and more) will also count toward the formal field experience 
evaluation. Ongoing evaluation offers a necessary benchmark to measure the student's level of progress and professional growth during the course of the field experience.

The supervisor of the LSU field experience evaluated the student on each of projects selected for the field experience. The student to followed a weekly schedule and documented the hours on an Excel $^{\circledR}$ spreadsheet spent working on each project - the log was updated every two weeks and emailed to the supervisor for evaluation. During the weekly meetings, the student shared progress reports, which the supervisor used as part of the evaluation process. The supervisor submitted a formal written evaluation to the LSU SLIS dean, and a subsequent meeting with the student, supervisor, and SLIS dean occurred to share the results of the evaluation. The supervisor also submitted documentation in a separate format to the LSU Libraries dean.

\section{B. PARADIGM FOR STUDENTS}

\section{Awareness}

The first step for library school students consists of developing their awareness of field experience opportunities and internships available at their institutions. Course descriptions appearing on library school websites or in catalogs list the field experience requirements and prerequisites. The library school faculty may also speak about the professional benefits of participating in a field experience program during the new student orientation. Students can also network with peers who have participated (or are interested) in field experiences or internships in order to exchange information and ideas. In the absence of a formal program, students can ask their advisors about the possibility of designing an independent study with a field experience component. Library conferences also serve as a common venue for library schools and recruiting libraries to 
market their field experience or internship programs, and for the supervisors and their trainees to share their experiences. Students should network at conferences in order to meet potential supervisors and to inquire about field experience opportunities. In addition, library periodicals provide a rich source of information related to field experience programs and internships. Students are advised to explore all of these resources to develop their awareness of the field experience options available at their library schools.

The LSU SLIS student desired hands-on experience to make a successful transition into the profession. The student initially became aware of the field experience program while attending a new student orientation during the first few days of the Masters in Library and Information Science (MLIS) program. Becoming familiar with the LSU SLIS field experience guidelines enhanced the student's awareness of the program and lead to discussions with the SLIS faculty advisor. In addition, reading about the field experiences and internships of other students and librarians in library journals further strengthened the student's interest to participate in the program. Developing an initial awareness of the program and its merits served as the primary impetus for the student to decide to explore options for a field experience.

\section{Interests}

Field experience candidates should closely examine their interests before embarking on a field experience. Educational background and work experience (particularly in a library or information center) may help students determine an appropriate area for a field experience. Core and specialization courses, which provide the theoretical foundations necessary for the field experience, also provide a logical 
starting point for students to identify an area of interest for a possible practicum. The key to a successful field experience (and possible future career) consists of identifying the area of library and information science of the most interest to the student. Is the student interested in pursuing a career in an academic, public, or special library? Does a career in reference or technical services appeal to the student? What field experience projects will provide the professional experience necessary to find employment after graduation? A student should carefully consider these questions prior to the field experience. Ultimately, the career goals of the student, including the type of library and the position, will determine the components of the field experience.

In the current study, the participant chose a field experience setting that corresponded to his professional goals and background. By the end of the first semester (as advised by the faculty), the student chose academic librarianship because it related to his past experience teaching and an interest in pursuing a university career. A predominant interest in core and specialization courses in academic librarianship also contributed to the participant's desire for a field experience set in a university library. The student's educational background in entomology and work experience as an agricultural sciences specialist contributed to the decision to design a field experience in agricultural librarianship. The academic core and specialization courses of the MLIS, combined with the student's past education and work experience, served to provide a strong foundation for the field experience and a future career as a science librarian.

\section{$\underline{\text { Planning }}$}

Preliminary planning on the part of the student is an essential element of the field experience. Reading the school's field experience guidelines and understanding the 
requirements will enable students to adequately plan for the experience. The field experience or practicum will involve a substantial time commitment, and students should allocate enough time in their schedules to satisfy the requirements. A list of field experience goals and objectives can serve as a useful planning tool for both the supervisor and student to identify projects germane to the participant's professional interests. The participant should communicate with student peers (including those who have completed or are currently participating in a practicum) considering a field experience to share ideas and information. Discussions with the faculty advisor or dean will help the student to plan appropriately and to register for courses that complement the field experience. For example, students planning a field experience with the library web coordinator may wish to register for courses in electronic resources or web design. The faculty advisor or dean can also suggest potential settings and supervisors. A student should interview prospective supervisors to find an appropriate match for their professional interests. Following the steps presented in the planning stage will offer the student the advantage of designing an experience predicated upon the knowledge and input of faculty, student peers, and librarians.

The LSU SLIS participant carefully allocated an adequate amount of time to pursue the requirements of the field experience set forth in the SLIS guidelines. The student also worked on a task list of accomplishments and goals for the experience. The student networked with other students in the LSU SLIS program and obtained feedback and ideas from past field experience participants to use for planning. The SLIS dean worked closely with the student and provided advice and guidance to the student regarding all aspects of the field experience. Based on a recommendation from the dean, the student interviewed 
and selected the LSU Libraries agriculture librarian as the supervisor prior to registering for the field experience course. The supervisor also provided input and advice to help the student further plan the experience.

\section{$\underline{\text { Participation }}$}

The student should participate in a professional level project (or projects) during the course of the field experience. The supervisor should provide all appropriate training for the participant. In addition, the participant is encouraged to ask to share in the supervisor's daily work and to shadow the supervisor as much as possible. A student can shadow the supervisor on the reference desk, attend instruction sessions conducted by the supervisor, or observe the supervisor selecting materials. Observation or participation in any type of work on the professional level will help the student to acquire various professional skills. The student should also pursue opportunities for professional development. Participating in web casts, attending conferences with the supervisor, or attending in-house training sessions will substantially contribute to the student's professional development. Careful documentation of their participation in field experience projects, including hours devoted to the project and tasks completed is necessary for the success of the experience. The participant should maintain a record of both formal and informal meetings with the supervisor. A project portfolio showcasing the student's work and participation in the experience should be kept for prospective employers. Library schools typically require students to submit a final narrative report or analysis of the field experience, and the supervisor should also receive a copy for the purpose of evaluation. Students should take advantage of participating in a field 
experience by acquiring as much professional experience as possible and proactively learning about their chosen area of specialization from the supervisor.

The student in the present study participated almost exclusively in professional level work, including collection development, reference services, weeding, developing subject guides, and preparing database search guides and presentations for instruction sessions. The participant observed the supervisor select materials from the online vendor and shadowed on the reference desk. The student also met on numerous occasions with the supervisor both formally and informally. Informal meetings often took the form of sessions lasting for several hours with the student observing and sharing the professional duties of the librarian. Close contact with the supervisor enabled the student to learn about other aspects of professional librarianship, including service and research related activities for promotion and tenure, searching for employment, and interviewing skills. The student attended regular training sessions conducted for the professional librarians and participated in other forms of professional development. In addition, the student maintained an almost daily log that documented all of the meetings and work completed on the projects. The student developed an extensive project report containing a spreadsheet of hours spent on each project, instruction aids, subject guides, books selected, and a description of mentoring and career counseling, and other documentary evidence of the field experience. The student submitted a final project report to both the SLIS dean and the supervisor; the report helped the supervisor to prepare a final evaluation of student's field experience performance. Selections from the report were placed in the student's portfolio to show prospective employers.

\section{Designing a Successful Library School Field Experience: A Paradigm for Supervisors}




\section{"take in Figure 1"}

\section{Planning}

\section{Identify Projects}

- Projects consist of professional level work

- Projects correspond with student's professional goals and interests

\section{Planning Tools}

- Create an outline with percentage of time devoted to each project

- Maintain spreadsheet logging project hours

\section{Training}

\section{Professional Guidance}

- Provide professional training for each project

- Work together on projects

- Stay involved!
Ongoing Training

- Meet weekly

- Communicate via email \& telephone

- Seek student input

\section{Mentoring}

\section{Career Counseling}

- Suggest listservs

- Professional organizations

- Job web sites

- Cover interviewing skills

- Write letters of recommendation

\section{Establish Professional Rapport}

- View student as a potential colleague

- Develop a positive working relationship

- Maintain ties with student after graduation 


\section{Evaluation}

\section{Ongoing Evaluation}

- Evaluate and keep a record of each project

- Is student performing tasks in a timely manner?

- Is student acquiring professional skills and aptitude?
Field Experience Expectations

- Dean's expectations

- Student's expectations

- Supervisor's expectations

- Learn expectations before starting field experience 


\section{Designing a Successful Library School Field Experience: \\ A Paradigm for Students \\ "take in Figure 2"}

\section{Awareness}

\section{Information Resources}

- Attend new student orientation sessions

- Check the library school catalog and the web site for information

- Read about field experience programs in library and information science periodicals

\section{Networking}

- Network with SLIS faculty and university librarians to increase awareness of field experience opportunities

- Network at library conferences to find potential supervisors and inquire about field experience programs

\section{Interests}

\section{Identify Interests}

- Core and specialization courses should help students identify appropriate areas for field experiences

- Consider past education and work experience

\section{Career Goals}

- Choose a library or information center setting that corresponds to career goals

- Select projects that match interests and provide professional experience

\section{Planning}

\section{Preparation}

- Read field experience guidelines and expectations

- Allocate adequate time for the field experience

- Create a prioritized list of goals and objectives

\section{Communication}

- Communicate with student peers to share field experience ideas and information

- Discuss the field experience with faculty advisor and dean

- Interview potential field experience supervisors 


\section{Participation}

\section{Acquire Professional Experience}

- Participate in projects consisting primarily of professional level work

- Shadow and share in the supervisor's daily work

- Pursue professional development opportunities in the field experience setting

\section{Documentation}

- Document each completed project

- Keep a record of regular meetings with supervisor

- Submit a final report to faculty advisor/field experience supervisor and maintain a project portfolio

\section{DISCUSSION}

Field experiences and internships offer mutual benefits for students and their host institutions. Students can expect to acquire the professional experience needed to successfully find employment after graduation. Internships and field experiences offer an opportunity for students to directly work on projects and pursue professional development opportunities simply not available in the library school classroom. Students can take advantage of the mentoring and career counseling available from senior librarians and information specialists; in some cases, a professional position may open at the host institution for the student. Host institutions benefit from projects completed that normally would require hiring a part-time or temporary staff professional. Library school students can share the latest theoretical knowledge and trends learned in library school with their supervisors. And host institutions benefit from networking relationships created with faculty at library schools.

The field experience also provided a number of invaluable benefits for the supervisor. For example, the librarian acquired supervisory experience to add to his curriculum vitae, and the field experience will count as service toward tenure and promotion. Moreover, the field experience provided an opportunity for the librarian to 
work with the dean of the library school. Both the supervisor and the library directly benefited from the amount of professional work completed by the field experience participant. Further benefits for the supervisor included establishing a mentoring relationship and the satisfaction of seeing the protégé develop as an information professional and successfully find employment. The field experience also resulted in an unexpected friendship, and the supervisor hosted a special dinner for the student at the conclusion of the program.

The paradigm is based upon a highly successful field experience and will be shared for possible implementation with LSU SLIS and interested LSU Libraries supervisors in the future. The paradigm, however, is not specific to the LSU SLIS program and can be implemented at any library school for a variety of practicums and field experiences. The practical suggestions contained in the paradigm can be used in tandem with any formal procedures or specific guidelines to facilitate a successful outcome to a field experience. Supervisors and students can also adapt or use portions of the paradigm to fit their particular needs. The paradigm should be implemented at the outset of the field experience, but it also can function as a referral checklist during the course of a program. The paradigm offers an excellent starting point for anyone planning or participating in a field experience.

\section{CONCLUSION}

A successful library school field experience or internship can greatly facilitate a student's future professional career. The results of the symbiotic relationship of the current case study exceeded all expectations. The supervisor and student contributed to a discussion forum on field experiences and internships sponsored by the New Members 
Round Table (NMRT) at the 2003 ALA Midwinter Meeting. The SLIS participant joined the United States Agricultural Information Network (USAIN) and subsequently presented a contributed paper at the USAIN 2003 Conference. The supervisor wrote letters of recommendation for the student and gave advice on information to include in the student's resume. The career counseling and mentoring provided by the supervisor ultimately helped the student obtain a position as a science librarian at Kansas State University Libraries. In addition, the professional skills and experience acquired at the LSU Libraries offer continued benefits in the student's current professional career. Finally, the field experience association turned out to be an enduring professional relationship for both participants.

Field experience programs continue to play an essential role in library and information science education. Programs offer students a wonderful opportunity to acquire the professional level experience needed to find subsequent employment and simultaneously benefit host institutions. Proper planning and design is critical to ensure a rewarding and successful practicum or field experience. The goal of the current case study is to provide a useful and highly practical paradigm for field experience supervisors, students, and library school faculty to implement into their own programs.

\section{REFERENCES}

Becker, N.J. (2000), "Service Learning in the curriculum: Preparing LIS students for the next millennium", Journal of Education for Library and Information Science, Vol. 41 No. 4, pp. 285-93. 
Brewer, J (2001), "Reflections of an academic library residency program coordinator", in Cogell, R.V. and Gruwell, C.A. (Eds), Diversity in Libraries: Academic Residency Programs, Greenwood, Westport, Connecticut, pp. 7-16.

Coburn, L. (1980), Classroom and field: The internship in American library education, Queens College, Flushing, New York.

Cogell, R.V. and Gruwell, C.A. (Eds) (2001), Diversity in Libraries: Academic Residency Programs, Greenwood, Westport, Connecticut.

Creth, S. (1986), Effective on-the-job training: Developing library human resources, American Library Association, Chicago.

Daix, E.C. and Epps, S.K. (2001), “The University of Delaware library residency program: two former residents' perspectives", in Cogell, R.V. and Gruwell, C.A. (Eds), Diversity in Libraries: Academic Residency Programs, Greenwood, Westport, Connecticut, pp. 131-41.

Fischer, B. (1994), Mentoring, Library Association Publishing, London. Jain, P. (1999), “On-the-job training: a key to human resource development”, Library Management, Vol. 20 No. 5, pp. 283-94.

Lawson, A.V. (1981), “Recommended Guidelines for a post-master’s internship program", in Systems and Procedures Exchange Center, Internships in ARL Libraries, Association of Research Libraries, Washington, D.C., Kit 79 pp. 1-6.

Oberg, D. and Samek, T. (1999), "Humble empowerment: The LIS practicum”, PNLA Quarterly, Vol. 63 No. 3, pp. 20-2.

Paulson, K. (2003), "Recruitment, education, and retention of librarians: A response to the top issues", College and Research Libraries News, Vol. 64 No. 2, pp. 89. 
Rowley, J. (1999), “Work-based projects”, Education for Information, Vol. 17, pp. 24551.

Singleton, B. (2003), "Entering academic librarianship: Tips for library school students", College and Research Libraries News, Vol. 64 No. 2, pp. 84-6.

SLIS. (1995), Guidelines for Student Field Experience, School of Library and Information Science (SLIS), Louisiana State University. Available http://slis.lsu.edu/syllabi/7900/field_exp.pdf

Whitmire, E. (2001), "From theory to practice: out of graduate school and into academic library residency program", in Cogell, R.V. and Gruwell, C.A. (Eds), Diversity in Libraries: Academic Residency Programs, Greenwood, Westport, Connecticut, pp. 89-95.

Williamson, C.C. (1923), Training for Library Service, Carnegie Corporation, New York. 